\title{
Kinetical Parameters Evaluation for Microalgae-Bacteria Granules used for Waste Water Treatment
}

\author{
ELENA MANEA, COSTEL BUMBAC, ALINA BANCIU, CATALINA STOICA, MIHAI NITA-LAZAR* \\ National Research and Development Institute for Industrial Ecology - ECOIND, 71-73 Drumul Podul Dambovitei Str., \\ 060652, Bucharest, Romania
}

\begin{abstract}
A preliminary stage in developing numerical simulations of a biological process for wastewater treatment consists in evaluating the kinetic parameters of the studied process. The study shows results obtained by experimental and numerical evaluation of mixed microalgae-bacteria granules kinetical parameters. The results showed that operational parameters modulated the main kinetic parameters of biological processes involved in removal of organic load and nutrients from wastewater such as biomass production coefficient, endogenous decomposition rate, specific peak rate of growth, semisaturation constant, specific rate of nitrification and the specific denitrification speed. These key parameters were determined over time to evaluate the performance of microbial populations in microalgae-bacteria granules in different operational conditions. Tests have been carried out for various wastewater compositions to determine the versatility and adaptability of the technology.
\end{abstract}

Keywords: microalgae, bacteria, activated sludge

Population growth, industrialization and urbanization have generated an increase in wastewater flows and the more stringent environmental regulations led to the need for innovative treatment technologies, with high efficiencies and reduced operational costs $[1,2]$. Mathematical models implementation is needed both in the design phase and in the optimizing stage of wastewater treatment plants (WWTPs) [3]. Moreover, WWTPs have been a reservoir of antibiotic resistant bacteria from where they could spread to the environment $[4,5]$ where they need to be monitored to prevent any further human health issues $[6,7]$.

Compared to conventional activated sludge systems, algae based biological wastewater treatment solutions have the advantages of lower costs (due to the lack of aeration need), but the drawback of difficulties in solids separation from the effluent [8]. A solution to this drawback was identified in using granular structures of mixed microalgae and bacteria [9], the granules being obtained by a methodology similar to the one used for activated sludge granules [10, 11]. The advantage of this microalgae-bacteria system has been represented by a better harvesting and less expensive aeration (reducing by $60 \%$ the energy costs) [12]. The intertrophic relationships between microalgae and bacteria have been the key for this biotechnological progress $[13,14]$.

In this paper, a number of specific functions and parameters were defined and calculated experimentally (especially on nutrient shifts and process speeds) to achieve the equilibrium of each component and to obtain the corresponding differential equations of the mathematical model for microalgae-bacteria granules for biological wastewater treatment.

\section{Experimental part}

Variation of specific operating parameters

Laboratory tests were designed to evaluate the influence of operational parameters on the balance between microalgae and bacterial species in granules. The monitored operational parameters modulated were: $\mathbf{Y}$ - biomass yield coefficient (ratio between formed biomass and consumed substrate); kd - decay coefficient (decomposed biomass during endogenous respiration reported on time); $\boldsymbol{\mu m a x}$, maximum growth rate; Ks - the semisaturation constant; $\mathbf{q N}$ - the specific nitrification rate; $\mathbf{q D}$ - the specific denitrification rate.

The test was performed in two photobioreactors operated in sequential batch mode (Feed-Reaction-SedimentationEvacuation) during successive cycles of 24 hours (Table 1). The treatment process was carried out in the absence of an external aeration source, the oxygen required for the aerobic metabolic processes being supplied exclusively through photosynthesis by the photoautotrophic microalgae in the light phase.

*email:mihai.nita@incdecoind.ro 
Table 1

OPERATIONAL PARAMETERS

\begin{tabular}{|c|c|}
\hline Parameter & 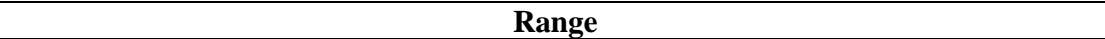 \\
\hline Photoperiodicity & $\begin{array}{l}\text {-15 h light: } 9 \text { h dark } \\
\text {-Continuous light }\end{array}$ \\
\hline Light source & $\begin{array}{l}\text {-Fluorescent lamp with a luminous flux of } 3980 \mathrm{~lm} \text {, the light intensity at the outside of } \\
\text { the bioreactor being } 215 \mu \mathrm{mol} / \mathrm{m} 2 / \mathrm{s} \\
\text {-Fluorescent lamp with a } 6600 \mathrm{~lm} \text { luminous flux, the light intensity at the outside of the } \\
\text { bioreactor being } 356 \mu \mathrm{mol} / \mathrm{m} 2 / \mathrm{s}\end{array}$ \\
\hline Mixer speed and type & $\begin{array}{l}\text {-Propeller type stirrer: } 160-900 \mathrm{rpm} \\
\text {-Rushton type stirrer: } 120-300 \mathrm{rpm}\end{array}$ \\
\hline $\mathrm{pH}$ & $\begin{array}{l}\text {-controlled at } 7.5 \pm 1 \\
\text {-uncontrolled }\end{array}$ \\
\hline $\begin{array}{c}\text { Biomass concentration } \\
\text { (microalgae-bacteria granules) }\end{array}$ & $0.8-4.2 \mathrm{~g} / \mathrm{L}$ \\
\hline Influent quality & $\begin{array}{l}\text { Synthetic Wastewater with Sodium Acetate as the unique source of organic carbon, } \\
\text { macro and micro-elements. Various quality parameters: CODCr }(300-660 \mathrm{mg} / \mathrm{L}) ; \mathrm{NH}_{4}{ }^{+} \\
(18-35 \mathrm{mg} / \mathrm{L}) ; \mathrm{PO}_{4}{ }^{3-}(3,6-14,3 \mathrm{mg} / \mathrm{L}) ;\end{array}$ \\
\hline
\end{tabular}

During the experiments, the organics concentration was monitored, measured as chemical oxygen demand (CODCr) ( $\mathrm{mg} \mathrm{O}_{2} / \mathrm{L}$ ) using SR ISO 6060-1996, while the volatile substances (VS) were gravimetrically determined according to STAS 6953-81.

VS determination was performed as average of triplicate from three independent samples, while $\mathrm{COD}$ was determined in duplicate from two independent samples. $\mathrm{NH}_{4}^{+}, \mathrm{NO}_{2}^{-}, \mathrm{NO}_{3}{ }^{-}$ and $\mathrm{PO}_{4}{ }^{3-}$ were determined according to SR EN ISO 14911: 2003 and SR EN ISO 10304/1: 2009 using the ICS-3000 ion chromatography system (Dionex, USA).

\section{Results and discussions}

Evaluation of the specific biomass yield (Y) and decay rate were essential for analyzing the potential biomass production during biological processes from the active microalgae-sludge symbiotic aggregates. In order to quantify the biomass production, it was necessary to monitor the volatile compounds (VS) and the organic load (samples filtered on $0.45 \mu \mathrm{m}$ pores filters) at hourly intervals. VS evolution was represented throughout logarithmic curves and COD was represented throughout polynomial curves. This created the preconditions of obtaining the compounds consumption profiles in the wastewater under the action microalga-bacterial granular aggregates (baseline control and after $1,2,3,4,5,6,7,8,9,10,11,12,22,23,24 \mathrm{~h}$ of operation). The difference between the two experimental configurations consisted in the use of different volumes of influent in the A1 and A2 bioreactors $(1.5 \mathrm{~L}$ for A1 and $4 \mathrm{~L}$ for A2) which led to reduced light homogeneity in the A2 bioreactor.

The results showed that the operational conditions in A1 were more suitable for the microalgae-bacteria bacteriabased biological process, resulting increased organics removal rates (Fig.1) compared to A2 (Fig. 2). Moreover, the VS seemed to steadily increase in A1 operating conditions (Fig. 1), while it reached a plateau in A2 at around 900mg/l (Fig. 2).

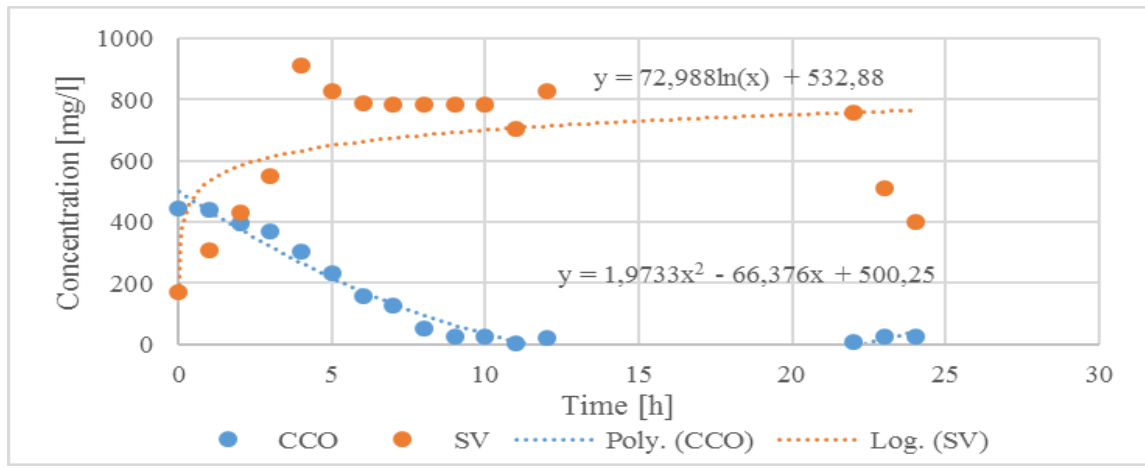

Fig. 1. Variation of organic load and biomass concentration in A1 over 24 hours. 


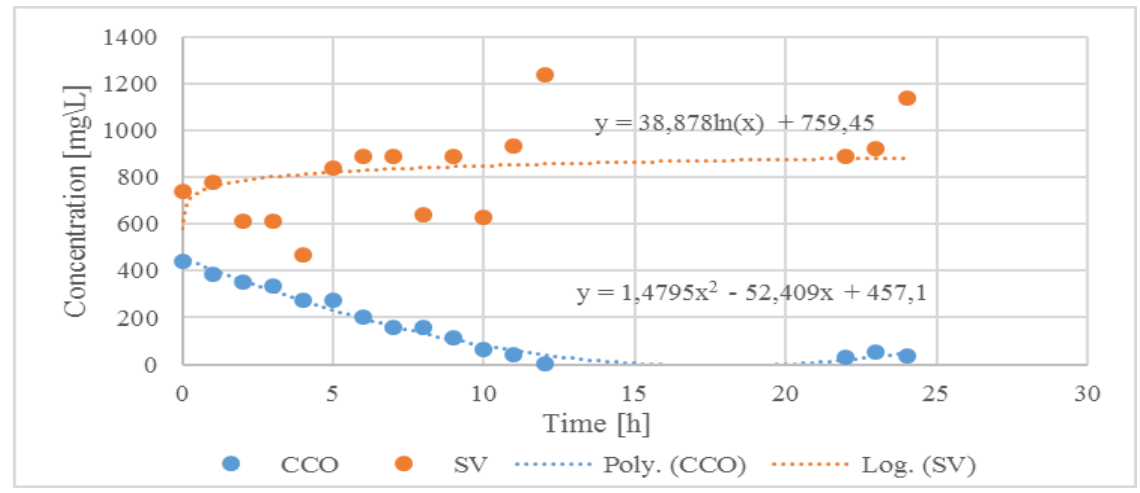

Fig. 2. Variation of organic load and biomass concentration in A2 over $24 \mathrm{~h}$

Based on the COD and VS curves equations, values were calculated, these values being considered in the Ui calculation using relations 1 and 2. Based on the equation $3 \mathrm{Ui}$ and $\mu \mathrm{i}$ were represented (Fig. 3 and 4). kd value was obtained from the intersection of the straight line with the $\mu \mathrm{i}$ axis, $\mathrm{Y}$ being the slope of the regression line.

$$
\begin{aligned}
& U_{i}=\frac{\left(s_{i-1}-s_{i}\right) / \Delta t_{i}}{\left(x_{i-1}+X_{i}\right) / 2} \\
& \mu_{i}=\frac{\left(x_{i}-X_{i-1}\right) / \Delta t_{i}}{\left(x_{i-1}+X_{i}\right) / 2} \\
& \mu=Y * U-k_{d}
\end{aligned}
$$

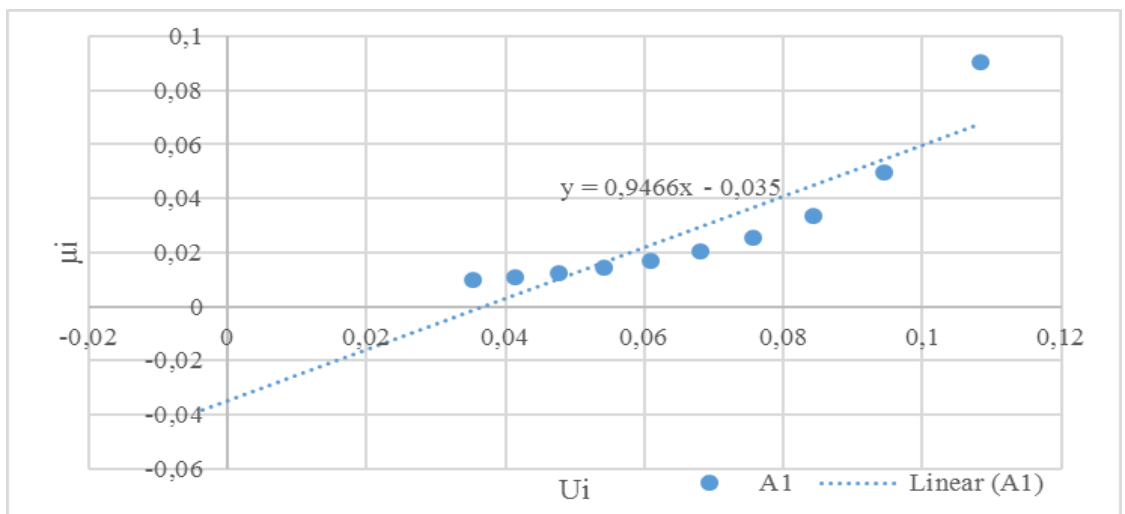

Fig. 3. Y and kd in A1 operational conditions

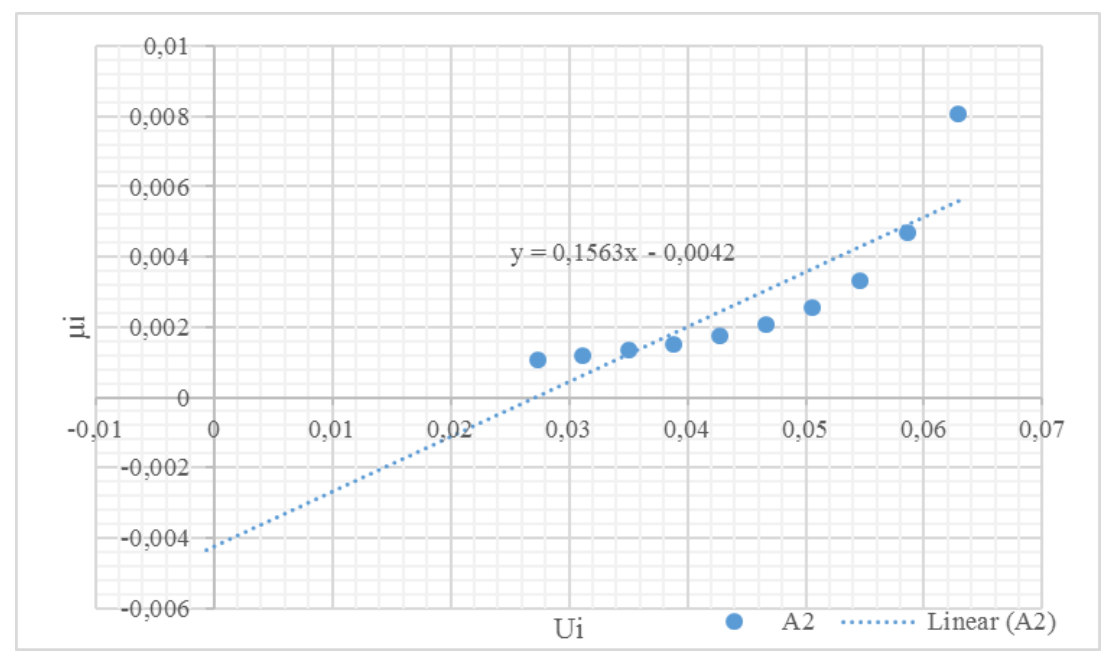

Fig. 4. $\mathrm{Y}$ and $\mathrm{kd}$ in $\mathrm{A} 2$ operational conditions

$\mathrm{Y}$ and kd values were calculated based on two tests performed on the degradation efficiency of microalgae-bacteria granules: test 1), $0.9466 \mathrm{mg} \mathrm{VS} \mathrm{/} \mathrm{mg} \mathrm{COD}$ and $0.035 \mathrm{~L} / \mathrm{h}$ for A1 and test 2), $0.1563 \mathrm{mg} \mathrm{VS} / \mathrm{mg}$ COD and $0.0042 \mathrm{~L} /$ $\mathrm{h}$ for A2. The difference between the two sets of values resulted from the different conditions in the bioreactors during the two experimental studies. 
Monod type equations resulted from previous research as used for determining the effect of substrate concentration on the growth of nitrifying microorganisms. The effect of $\mathrm{NH}_{4}{ }^{+}$and the concentration of dissolved oxygen on the nitrifying microorganisms growth rate (considering the limiting case of Nitrosomonas) can be described according to equation 4:

$$
\mu_{N}=\mu_{N \max }\left[\frac{N H_{4}^{+}-N}{K_{N}+N H_{4}^{+}-N}\right]\left[\frac{O D}{K_{0}+O D}\right]
$$

where:

$\mu_{N}$ - the specific growth rate of nitrifying micro-organisms,

$\mu_{N \max }$ - the maximum growth rate of nitrifying micro-organisms,

$K_{N}$ - semisaturation constant for $\mathrm{NH}_{4}^{+}$,

$\mathrm{OD}$ - dissolved oxygen concentration,

$K_{N}$ - Oxygen semisaturation constant.

The ammonium oxidation rate was detected by considering the concentration of $\mathrm{N}^{-\mathrm{NH}_{4}}{ }^{+}$reduced per hour per gram of VS. qN values (specific oxidation rates) obtained from experimental data $(1.74 \mathrm{mg} / \mathrm{g} / \mathrm{h}$ for A1 and $1.33 \mathrm{mg} / \mathrm{g} / \mathrm{h}$ for A2) had values similar to those identified in literature (1-3 mg/g/h). The ammonia oxidation rates calculated for each of the cases are: $2.51 * 10^{-3} \mathrm{mg} \mathrm{N} / \mathrm{mgVS} / \mathrm{h}$ for A1 and $1.79 * 10^{-3} \mathrm{mg} \mathrm{N} / \mathrm{mgVS} / \mathrm{h}$ for A2.

The denitrification rate is determined by considering the specific denitrification rate $\left(\mathrm{mg} \mathrm{N}^{-} \mathrm{NO}_{2}^{-}+\mathrm{N}^{-} \mathrm{NO}_{3}{ }^{-}\right.$ $/ \mathrm{mgVS} / \mathrm{h})$, the cumulative nitrite and nitrate concentration over time. The denitrification rates obtained in the two cases: $2.14^{*} 10^{-3} \mathrm{mg} \mathrm{N} / \mathrm{mg} \mathrm{VS} / \mathrm{h}$ for A1 and $7.5^{*} 10^{-4} \mathrm{mgN} / \mathrm{mg} \mathrm{VS} / \mathrm{h}$ for A2.

\section{Conclusions}

The balance between microalgae and bacterial species from granules was modulated by the main kinetics factors. Two different experiments were designed and hourly samples were analyzed. The results were used in evaluating several kinetic parameters, as were $\mathbf{Y}$ - biomass yield coefficient (ratio between formed biomass and consumed substrate); kd - decay coefficient (decomposed biomass during endogenous respiration reported on time); $\boldsymbol{\mu m a x}$, maximum growth rate; Ks - the semisaturation constant; $\mathbf{q N}$ - the specific rate of nitrification; $\mathbf{q D}$ - the specific denitrification rate. The kinetic parameters evaluation methodology was validated, the results reliability being backend by their similarity to the ones in the specific literature.

Acknowledgements: This work was financially supported by grant PN-III-P4-ID-PCE-2016-0865 from the Romanian National Authority for Scientific Research and Innovation CNCS/CCCDI-UEFISCDI.

\section{References}

1. STOICA C., GHEORGHE S., PETRE J., LUCACIU I., NITA-LAZAR M., Environ. Eng. Manag. J., 13, no. 9, 2014 , p. 2243.

2. NITA-LAZAR M., GALAON T., BANCIU A., PAUN I., STOICA C., LUCACIU I., J. Environ. Prot. Ecol., 17, no. 1, 2016 , p. 237.

3.GIONA A. R., ANNESINI M. C., TORO L., GERARDI W., J. Water Pollut. Control Fed., 51, no. 5, 1979, p. 999.

4. BANCIU A., NICULESCU D., NITA-LAZAR M., LUCACIU I., STOICA C., MIHAESCU G., J. Environ. Prot. Ecol., 17, no. 1, 2016, p. 127.

5. CATRANGIU A., NICULESCU D, LUCACIU I., CHIFIRIUC C., MIHAESCU G., J. Environ. Prot. Ecol., 16, no. 1, 2015 , p. 33.

6. ANCUTA PN, ATANASESCU A., SOREA S., LUCACIU I., STOICA C., NITA-LAZAR M., BANCIU A, Control. Eng. Appl., 21, no. 2, 2019 , p. 54.

7. STOICA C., ANCUTA PN, LUCACIU I., BANCIU AR, SOREA S., ATANASESCU A., LAZAR MN, Rev. Chim. (Bucharest), 69, no. 11, 2018, p. 4166.

8. TIRON O., BUMBAC C., PATROESCU I. V., POSTOLACHE C., Water Sci. Technol., 69, no. 8, 2014, p. 1598.

9. TIRON O., BUMBAC C., PATROESCU I. V., BADESCU V.R., POSTOLACHE C., Water Sci. Technol., 71, no. 6, 2015 , p. 832.

10. BUMBAC C., IONESCU I. A., TIRON O., BADESCU V. R., Water Sci. Technol., 71, no. 3, 2015, p. 440.

11. KREUK M.K. , KISHIDA N. VAN LOOSDRECHT M.C.M., Water Sci. Technol., 55, no. 8-9, 2007, p. 75.

12. TIRON O., BUMBAC C., MANEA E., NITA-LAZAR M., Scientific Rep., 7, 2017.

13. BUMBAC C., MANEA E., BANCIU A., STOICA C., IONESCU I., BADESCU V., LAZAR MN, Rev. Chim. (Bucharest), 70, no. 1, 2019, p. 275.

14. BUMBAC C., MANEA E., STOICA C., BANCIU A., IONESCU L., BADESCU V., NITA-LAZAR M., Rev. Chim. (Bucharest), 70, no. 1, 2019 , p. 319.

$\overline{\text { Manuscript received: } 31.07 .2019}$ 
